\title{
Effect of Carbon and Nitrogen on Work-hardening Behavior in Metastable Austenitic Stainless Steel
}

\author{
Takuro MASUMURA ${ }^{1,2) *}$ and Toshihiro TSUCHIYAMA ${ }^{1,2,3)}$ \\ 1) Department of Materials Science and Engineering, Kyushu University, 744 Moto-oka, Nishi-ku, Fukuoka, $819-0395$ Japan. \\ 2) International Institute for Carbon-Neutral Energy Research, Kyushu University, 744, Moto-oka, Nishi-ku, Fukuoka, $819-0395$ \\ Japan. \\ 3) Research Center for Steel, Kyushu University, 744 Moto-oka, Nishi-ku, Fukuoka, 819-0395 Japan.
}

(Received on August 28, 2020; accepted on September 30, 2020)

\begin{abstract}
The effects of $\mathrm{C}$ and $\mathrm{N}$ on the work-hardening behaviors were compared in metastable austenitic steels in which varied amounts of $\mathrm{C}$ and $\mathrm{N}$ were separately added (Fe- $18 \% \mathrm{Cr}-8 \% \mathrm{Ni}-(\mathrm{C}, \mathrm{N})$ alloys). Although both $\mathrm{C}$ and $\mathrm{N}$ suppressed deformation-induced martensitic transformation during tensile deformation due to their austenite-stabilizing effect, they enhanced the work hardening of the steels. Comparison of $\mathrm{C}$-added and $\mathrm{N}$-added steels revealed that $\mathrm{C}$ addition more increased the work-hardening rate than $\mathrm{N}$ addition. In order to clarify the reason of the more significant effect of $\mathrm{C}$, the individual hardness of deformed austenite and deformation-induced martensite (DIM) were measured in cold-rolled C-added and N-added steels by using a nano-indentation tester. The nanohardness of deformed austenite increased with increasing the thickness reduction and amount of added $\mathrm{C}$ and N. However, there is little difference between C-added and $\mathrm{N}$-added steels in the hardening behavior of austenite, meaning that the difference in work-hardening rate of metastable austenitic steel between $\mathrm{C}$-added and $\mathrm{N}$-added steels is not derived from the hardness of deformed austenite but that of DIM. The nanohardness of DIM was significantly higher in the C-added steel than $\mathrm{N}$-added steel, and thus, the main factor affecting the higher work hardening of $0.1 \mathrm{C}$ steel should be considered to be the higher hardness of C-containing DIM. In addition, in C-added steels, an excellent strength-ductility balance was achieved compared with $\mathrm{N}$-added steel because the hard DIM is gradually formed until the later stage of deformation, meaning that pronounced TRIP effect was obtained in $\mathrm{C}$-added steels than $\mathrm{N}$-added steels.
\end{abstract}

KEY WORDS: TRIP effect; deformation-induced martensite; metastable austenitic stainless steel; carbon; nitrogen; secant method.

\section{Introduction}

Metastable austenitic stainless steel, represented by $\mathrm{Fe}-18 \% \mathrm{Cr}-8 \% \mathrm{Ni}$ alloy, is known to undergo deformationinduced martensitic transformation (DIMT) during deformation, ${ }^{1,2)}$ which leads to a transformation-induced plasticity (TRIP) effect. Since this type of steel exhibits a moderate work-hardening that continues until the later stage of deformation owing to the TRIP effect, it shows a large uniform elongation during tensile testing, as well as an excellent press formability. In addition, cold-worked metastable austenitic stainless steels are widely applied as high-strength plate and wire steels because their strength can be increased significantly by cold working. For applications requiring further strengthening, the work hardening of the steel is enhanced by the addition of C and N. For example, SUS301

\footnotetext{
*Corresponding author: E-mail: masumura@zaiko.kyushu-u.ac.jp
}

$(\mathrm{C}<0.15 \%)$, SUS304N1 $(0.1 \%<\mathrm{N}<0.25 \%)$, etc. are practically used as high-strength springs, structural materials for vehicles, and so forth. Therefore, it is necessary to accurately understand the effects of $\mathrm{C}$ and $\mathrm{N}$ on the DIMT and accompanying work hardening in order to improve the formability and strength of stainless steel plates and wires.

The reason why adding $\mathrm{C}$ and $\mathrm{N}$ enhances work hardening of metastable austenitic steel could be because $\mathrm{C}$ and $\mathrm{N}$ affect the work hardening of the austenite matrix itself and the amount and strength of deformation-induced martensite (DIM). Yoshitake et al. ${ }^{3)}$ investigated the work-hardening behavior of austenite using stable austenitic stainless steel (Fe-18\% Cr- $12 \% \mathrm{Ni}$ alloy) with $0.1 \% \mathrm{C}$ and $\mathrm{N}$ separately and reported that a higher work hardening rate was observed in the $\mathrm{C}$-added steel due to the frequent formation of deformation twins in the high-strained region. On the other hand, the stability of austenite also influences the work-hardening behavior of metastable austenitic stainless steel. Because C 
and $\mathrm{N}$ are strong austenite-stabilizing elements and retard DIMT, they may have an effect to reduce the work hardening to some extent. However, they simultaneously could contribute to increasing work-hardening rate through the hardening of DIM. Considering that DIM bears significant stress as a hard phase, not only its amount is critical, but its hardness is also an important factor in determining the work-hardening behavior.

In the above viewpoint, there is a difference in the effects of $\mathrm{C}$ and $\mathrm{N}$; $\mathrm{C}$ is more effective in increasing the mechanical stabilization of austenite than $\mathrm{N},{ }^{4-6)}$ whereas it is generally accepted that $\mathrm{C}$ is more effective in increasing the hardness of athermal martensite formed by quenching than $\mathrm{N}^{7-10)}$ Therefore, the effects of $\mathrm{C}$ and $\mathrm{N}$ on the work-hardening behavior of metastable austenitic steel are expected to be different; nevertheless, no systematic investigation has been done.

In this study, the work-hardening behavior in C- and $\mathrm{N}$-added metastable austenitic stainless steel was compared, and then, the differences was discussed in terms of the effects of $\mathrm{C}$ and $\mathrm{N}$ on the strength of DIM. DIM has a fine structure because it is highly nucleated at deformation twins, $\varepsilon$-martensite, and dislocation structures in the austenite matrix. Therefore, the hardness of DIM was evaluated using the nano-indentation test. In addition, the amount of stress that DIM bears during tensile testing was estimated by micromechanical calculation using the secant method. ${ }^{11)}$ In the usual use of secant method, the stress-strain curve of a multiple phase steel is calculated from the stress-strain curves and the volume fraction of each phase. On the other hand, in this study, the stress-strain curve of metastable austenitic stainless steel, which should be treated as output data usually, was experimentally obtained and used to obtain the stress-strain curve of DIM by solving the inverse problem.

\section{Experimental Procedure}

A metastable austenitic stainless steel without the addi- tion of $\mathrm{C}$ and $\mathrm{N}(\mathrm{Fe}-18 \% \mathrm{Cr}-8 \% \mathrm{Ni})$ was used as the base steel in this study. To obtain $\mathrm{C}$ - and $\mathrm{N}$-bearing specimens, $0.021 \%$ C, $0.051 \%$ C, $0.100 \%$ C, $0.199 \%$ C, $0.015 \%$ N, $0.030 \% \mathrm{~N}, 0.063 \% \mathrm{~N}, 0.100 \% \mathrm{~N}$, and $0.196 \% \mathrm{~N}$ were separately added to the Base steel, and the respective chemical compositions (mass\%) are listed in Table 1. Each steel was produced by vacuum melting to obtain a $17 \mathrm{~kg}$ ingot and then hot-rolled at $1423 \mathrm{~K}$. The resultant steel plates were cold-rolled to achieve $60 \%$ reduction in thickness and then solution-treated at temperatures in the range $1273-1473 \mathrm{~K}$ for $1.8 \mathrm{ks}$ (solution-treated specimens), followed by water cooling to obtain the initial austenitic structure with an average grain size of approximately $40 \mu \mathrm{m}$. Some specimens were cold-rolled again to investigate the work-hardening behavior (cold-rolled specimens). The cold-rolled specimens were water-cooled after each rolling pass to prevent exposure to heat produced during processing. Tensile testing was conducted at ambient temperature at a strain rate of $5.6 \times 10^{-5} \mathrm{~s}^{-1}$ for the solution-treated plate specimens with the gauge dimensions of $18 \times 3 \times 1.5 \mathrm{~mm}$ (length $\times$ width $\times$ thickness). In addition, stable austenitic stainless steels $(\mathrm{Fe}-18 \% \mathrm{Cr}-12 \% \mathrm{Ni}-0.1 \% \mathrm{C}$ and $\mathrm{N})$ were prepared to obtain the input data for the secant method, and the chemical compositions are listed in Table 1 . The specimens were solution-treated at $1473 \mathrm{~K}$ for $1.8 \mathrm{ks}$, followed by water cooling. Furthermore, the recrystallizing treatment was performed at $1373 \mathrm{~K}$ for $150 \mathrm{~s}$ after $90 \%$ cold rolling to control the austenite grain size of approximately $40 \mu \mathrm{m}$. After that, tensile testing was conducted, and we confirmed that DIMT does not occur during tensile testing.

The saturation magnetization of specimens (Is) and that of a reference with the full martensitic structure $\left(I s^{*}\right)$ were measured, and the volume fractions of DIM $\left(V_{\alpha}\right)$ in the deformed specimens were evaluated by $I s / I s{ }^{*}$. Base steel, $85 \%$ cold-rolled at $77 \mathrm{~K}$, whose microstructure was confirmed by the neutron diffraction analysis to be $99.5 \%$ martensitic structure, ${ }^{12)}$ was used as the reference for obtaining $I s^{*}$. The microstructures of the specimens were

Table 1. Chemical compositions (mass\%) of the specimens used in this study.

\begin{tabular}{ccccccccccc}
\hline & $\mathrm{C}$ & $\mathrm{Si}$ & $\mathrm{Mn}$ & $\mathrm{P}$ & $\mathrm{S}$ & $\mathrm{Cr}$ & $\mathrm{Ni}$ & $\mathrm{N}$ & $\mathrm{Fe}$ \\
\hline \multicolumn{1}{c}{ Metastable austenitic stainless } & steels (Fe-18.3\%Cr-8.2\%Ni-(C,N) alloy) & & \\
\hline Base steel & 0.002 & 0.48 & 0.98 & 0.035 & 0.002 & 18.07 & 8.21 & 0.001 & bal. \\
$0.02 \mathrm{C}$ steel & 0.021 & 0.47 & 1.02 & 0.034 & 0.002 & 18.21 & 8.20 & 0.002 & bal. \\
$0.05 \mathrm{C}$ steel & 0.051 & 0.48 & 1.02 & 0.033 & 0.002 & 18.24 & 8.13 & 0.002 & bal. \\
$0.1 \mathrm{C}$ steel & 0.100 & 0.49 & 0.98 & 0.034 & 0.002 & 18.26 & 8.19 & 0.006 & bal. \\
$0.2 \mathrm{C}$ steel & 0.199 & 0.47 & 0.98 & 0.034 & 0.002 & 18.27 & 8.18 & 0.006 & bal. \\
$0.015 \mathrm{~N}$ steel & 0.001 & 0.49 & 1.00 & 0.030 & 0.002 & 18.21 & 8.23 & 0.015 & bal. \\
$0.03 \mathrm{~N}$ steel & 0.001 & 0.49 & 1.01 & 0.031 & 0.002 & 18.28 & 8.22 & 0.030 & bal. \\
$0.06 \mathrm{~N}$ steel & 0.001 & 0.47 & 1.00 & 0.029 & 0.002 & 18.30 & 8.15 & 0.063 & bal. \\
$0.1 \mathrm{~N}$ steel & 0.003 & 0.48 & 0.99 & 0.035 & 0.002 & 18.05 & 8.23 & 0.100 & bal. \\
$0.2 \mathrm{~N}$ steel & 0.003 & 0.48 & 0.99 & 0.035 & 0.002 & 18.18 & 8.22 & 0.196 & bal. \\
\hline & Stable austenitic stainless steels (Fe-18\%Cr-12\%Ni-(C,N) alloy) & & \\
\hline $18 \mathrm{Cr}-12 \mathrm{Ni}$ & 0.0013 & $<0.05$ & $<0.05$ & $<0.01$ & $<0.01$ & 18.02 & 11.94 & 0.0007 & bal. \\
$18 \mathrm{Cr}-12 \mathrm{Ni}-0.1 \mathrm{C}$ & 0.092 & $<0.05$ & $<0.05$ & $<0.01$ & $<0.01$ & 17.98 & 12.10 & 0.0010 & bal. \\
$18 \mathrm{Cr}-12 \mathrm{Ni}-0.1 \mathrm{~N}$ & 0.0020 & $<0.05$ & $<0.05$ & $<0.01$ & $<0.01$ & 17.93 & 12.04 & 0.118 & bal. \\
\hline
\end{tabular}


analyzed by electron backscatter diffraction (EBSD) with a field-emission scanning electron microscope (SIGMA 500, Zeiss). The data obtained by EBSD were analyzed using software for automatic crystal orientation mapping (OIM (Orientation Imaging Microscopy) analysis, TSL solutions). Crystallographic orientation mapping was performed at step sizes of $200 \mathrm{~nm}$, and the data obtained with a confidence index (CI) value over 0.1 were used for the detailed crystallographic analysis. Nano-indentation experiments were carried out using a Hysitron Triboindenter (TI950, Bruker) at a maximum load of $1000 \mu \mathrm{N}$. Tip calibration analyses and hardness calculations were conducted using the Oliver and Pharr method. ${ }^{13)}$ All specimens for nano-indentation testing were polished mechanically and electropolished in a solution of $8 \%$ perchloric, $10 \%$ butylcellosolve, $60 \%$ ethanol, and $22 \%$ water at $273 \mathrm{~K}$ under an electric potential of $25 \mathrm{~V}$ to remove the strained layer. The indented points were selected by observing the specimen surface using the scanning probe microscope (SPM) function of the Triboindenter.

\section{Results and Discussion}

\subsection{Effect of Carbon and Nitrogen on the Hardness of Cold-rolled Specimens}

Figure 1 shows the change in the volume fraction of DIM as a function of thickness reduction by cold rolling. The addition of $\mathrm{C}$ and $\mathrm{N}$ improved the mechanical stability of austenite, and the volume fraction of DIM decreased with the $\mathrm{C}$ and $\mathrm{N}$ content. A comparison between $\mathrm{C}$ - and $\mathrm{N}$-added steels reveals that the volume fraction of DIM in $\mathrm{C}$-added steels is lower than that in $\mathrm{N}$-added steels, meaning that the mechanical stabilizing effect of $\mathrm{C}$ is higher than that of $\mathrm{N}$, as reported in a previous study. ${ }^{4-6)}$ In these steels, $\mathcal{\varepsilon}$-martensite with HCP structure is also formed as an intermediate phase of the $\gamma \hookrightarrow \alpha^{\prime}$ transformation, but we confirmed that the amount was small (5 vol.\% at most) and the $\varepsilon \rightarrow \alpha^{\prime}$ transformation was completed at $70 \%$ cold rolling for all steels. ${ }^{4)}$

Figure 2 shows phase + image quality (IQ) maps (a)-(c) and crystallographic orientation maps extracted only DIM (BCC) (d)-(f) in 20\% cold-rolled Base (a) (d), 0.1C (b) (e), and $0.1 \mathrm{~N}$ steel (c) (f). In the phase maps, austenite (FCC) and DIM (BCC) are colored gray and red, respectively. In Base steel, most of the austenite transformed to DIM, and fine blocks of several microns are observed. In the $0.1 \mathrm{C}$ and $0.1 \mathrm{~N}$ steels, DIM grains are aligned along straight lines within austenite grains, indicating that the DIM was nucleated in plate-like structures including deformation twins and $\mathcal{E}$-martensite developed in austenite. ${ }^{4,6,14-16)}$ The block size of DIM is fine, similar to that of Base steel. The effects of C and $\mathrm{N}$ on the mechanical stability of austenite, the transformation mechanism, and the crystallographic characteristics of DIM have already been studied in detail from the previous reports. ${ }^{4-6)}$

Figure 3(a) shows the changes in the hardness as a function of thickness reduction by cold rolling for Base, $0.1 \mathrm{C}$, and $0.1 \mathrm{~N}$ steels. The hardness of each steel increases with the reduction in the thickness, and the work hardening of $0.1 \mathrm{C}$ and $0.1 \mathrm{~N}$ steels are larger than that of Base steel despite of the smaller amount of DIM in 0.1C and $0.1 \mathrm{~N}$ steels. Therefore, it is found that the addition of $\mathrm{C}$ and $\mathrm{N}$ is effective in strengthening metastable austenitic stainless steel, although both elements suppress the DIMT. The comparison of $0.1 \mathrm{C}$ and $0.1 \mathrm{~N}$ steels revealed that the effect of $\mathrm{C}$ is higher than that of $\mathrm{N}$. The relation between the hardness and the volume fraction of DIM was shown in Fig. 3(b). The hardness of each steel increased with the amount of DIM. However, there was a remarkable difference in the hardening behavior; the hardness was significantly different even when the amount of DIM is the same for each steel. This result suggests that some factors, other than the volume fraction of DIM, significantly affect the work-hardening behavior of metastable austenitic stainless steel. Hence, the individual hardness values of deformed austenite and DIM were measured using nano-indentation tests for cold-rolled specimens. Figure 4 shows the SPM image of $20 \%$ cold-rolled Base steel after indentation (a), nanohardness of austenite (b), and DIM (c). As shown with the white arrows in the SPM image, the size of indentation is approximately $100-200 \mathrm{~nm}$, and therefore, it is possible to indent at the fine martensite phase. The regions of the flat surface (bottom right) and uneven surface corresponding to the substructure such as block (upper left) are austenite and DIM, respectively. The nanohardness of austenite increased with the reduction in thickness and the addition of $\mathrm{C}$ and $\mathrm{N}$. However, there is little difference between the $0.1 \mathrm{C}$ and $0.1 \mathrm{~N}$ steels, meaning that the work hardening of austenite influences the difference in the work-hardening behavior (shown in Fig. 3) to a limited extent. On the other hand, the nanohardness of DIM differs significantly among the various steels investigated, and the maximum hardness was (a) C-added steels

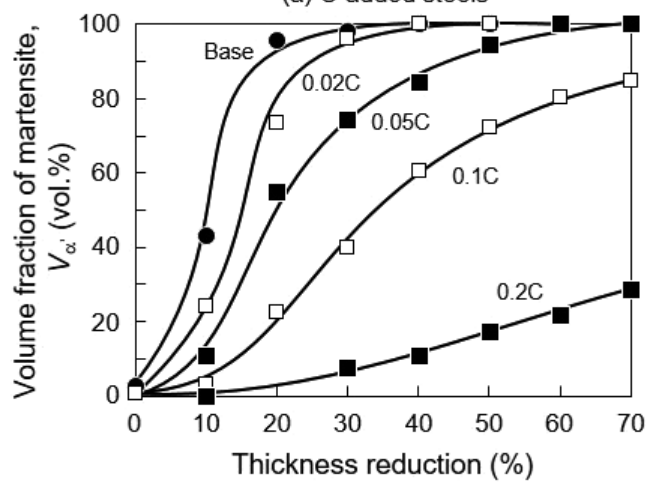

(b) $\mathrm{N}$-added steels

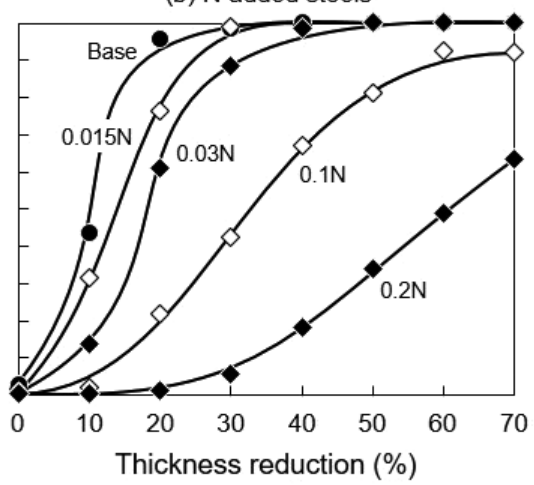

Fig. 1. Changes in volume fraction of DIM as a function of thickness reduction in cold-rolled C-added and N-added steels. 
Martensite (BCC) $\square$ Austenite (FCC)

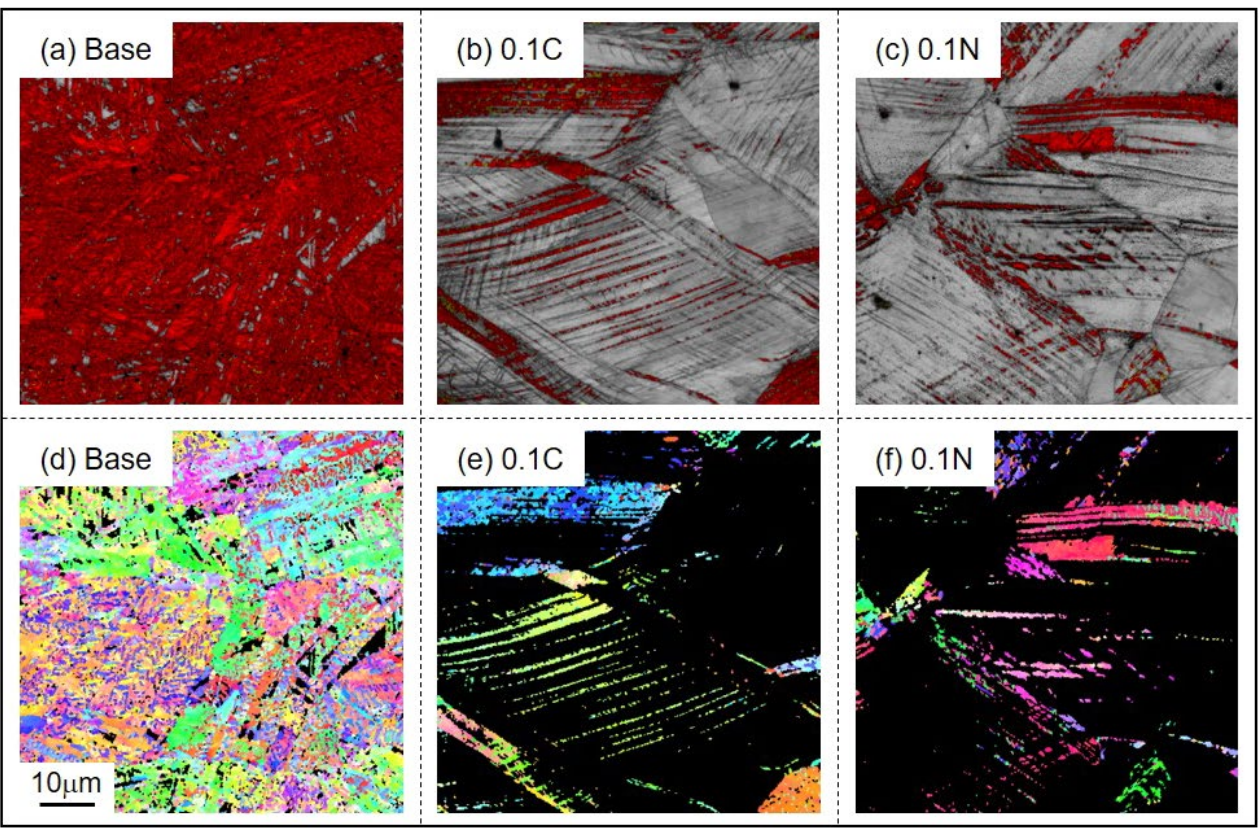

Fig. 2. Phase + IQ maps (a)-(c) and crystallographic orientation maps (BCC phase only) (d)-(f) of $20 \%$ cold-rolled Base (a) (d), 0.1C (b) (e) and 0.1N steel (c) (f). Gray and red represent austenite (FCC) and DIM (BCC), respectively. (Online version in color.)
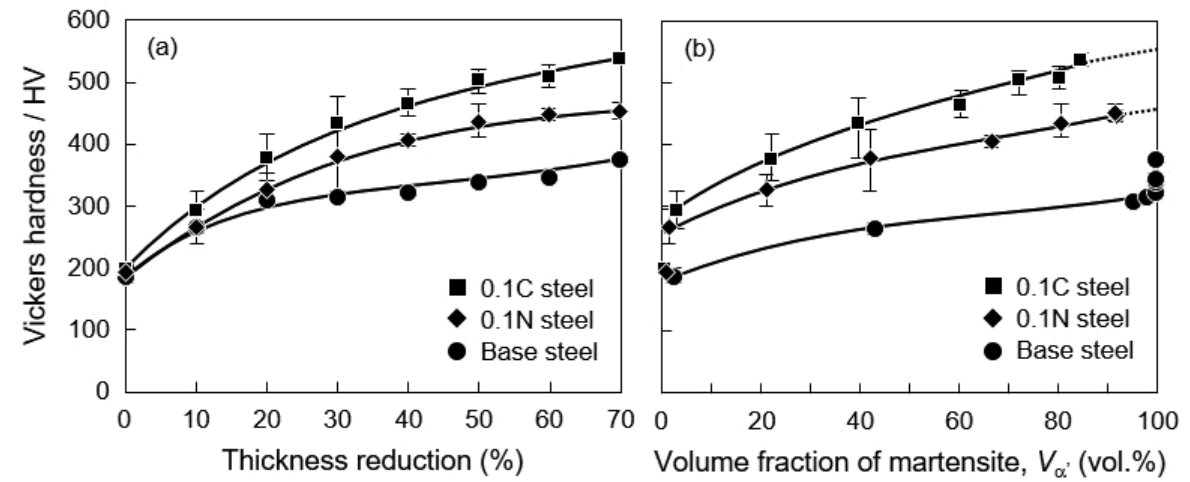

Fig. 3. Changes in Vickers hardness as a function of thickness reduction (a) and volume fraction of DIM (b) in coldrolled Base, $0.1 \mathrm{C}$, and $0.1 \mathrm{~N}$ steel.
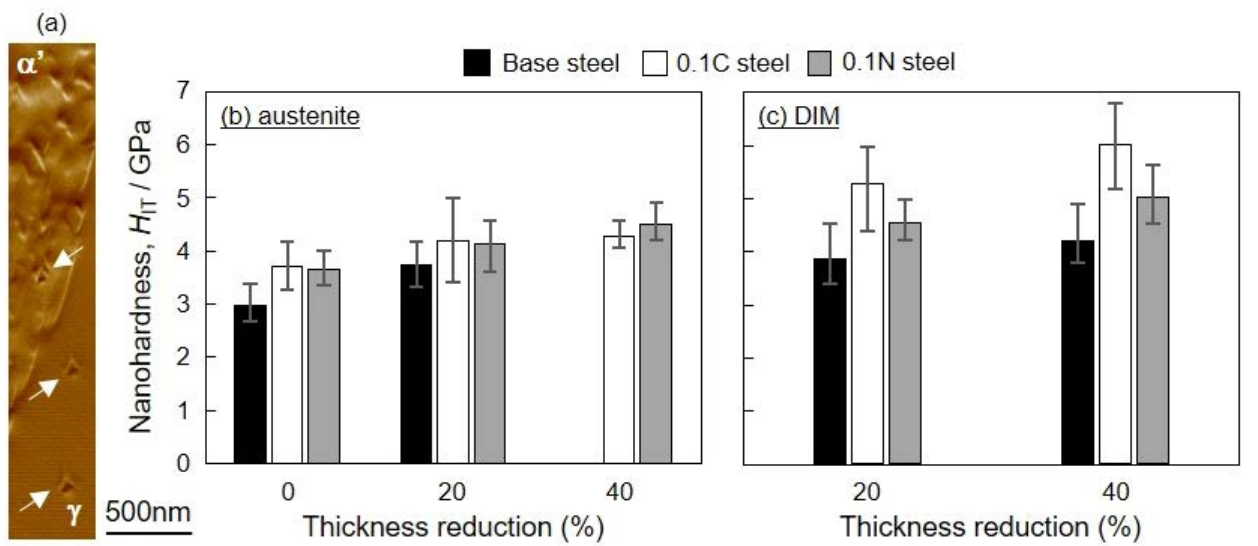

Fig. 4. Scanning probe microscope image of $10 \%$ cold-rolled $0.1 \mathrm{~N}$ steel (a). Nanohardness of austenite (b) and DIM (c) in cold-rolled Base, $0.1 \mathrm{C}$, and $0.1 \mathrm{~N}$ steel. (Online version in color.)

obtained for the $0.1 \mathrm{C}$ steel. Therefore, the higher hardeness of $\mathrm{C}$ for DIM is the main factor affecting the higher work hardening of $0.1 \mathrm{C}$ steel.
Figure 5 shows the changes in the Vickers hardness of DIM in 70\% cold-rolled specimens as a function of $\mathrm{C}$ and $\mathrm{N}$ contents. In Base, $0.02 \mathrm{C}, 0.05 \mathrm{C}, 0.015 \mathrm{~N}, 0.03 \mathrm{~N}$, and $0.06 \mathrm{~N}$ 
steel, the full martensitic structure was obtained by $70 \%$ cold rolling. Because retained austenite is present in $0.1 \mathrm{C}$ and $0.1 \mathrm{~N}$ steels, the values extrapolated the curve, shown in Fig. 3(b), to $100 \%$ DIM are plotted in Fig. 5 as the hardness of DIM of $0.1 \mathrm{C}$ and $0.1 \mathrm{~N}$ steels. Moreover, the hardness of the athermal martensite in martensitic stainless steel (Fe$12 \% \mathrm{Cr}-(\mathrm{C}, \mathrm{N})$ alloy) ${ }^{8)}$ was also plotted (open marks). The hardness of $\mathrm{Fe}-12 \% \mathrm{Cr}-4 \% \mathrm{Ni}$ alloy without $\mathrm{C}$ and $\mathrm{N}, \mathrm{Fe}-$ $12 \% \mathrm{Cr}-0.1 \% \mathrm{C}$ alloy, and $\mathrm{Fe}-12 \% \mathrm{Cr}-0.1 \% \mathrm{~N}$ alloy were 220 , 430 , and $350 \mathrm{HV}$, respectively. For the same $\mathrm{C}$ or $\mathrm{N}$ content, the hardness of DIM is more than $100 \mathrm{HV}$ higher than that of athermal martensite. This is because of the high dislocation density of DIM obtained by taking over the dislocation of austenite through the DIMT from deformed austenite. Focusing on the difference between $\mathrm{C}$ - and $\mathrm{N}$-added steel, it was found that the DIM of C-added steels is approximately $20 \%$ harder than that of $\mathrm{N}$-added steels, which is similar to the result of athermal martensite. For example, Tsuchiyama

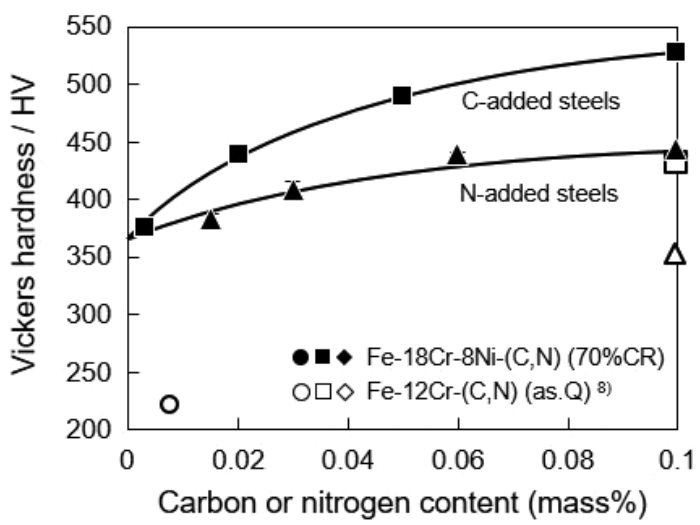

Fig. 5. Changes in the Vickers hardness of DIM in $70 \%$ coldrolled $\mathrm{Fe}-18 \mathrm{Cr}-8 \mathrm{Ni}-(\mathrm{C}, \mathrm{N})$ alloys (solid marks) and athermal martensite in as-quenched Fe-12Cr-(C,N) alloys ${ }^{8)}$ (open marks). et $a l .{ }^{7)}$ measured the nanohardness of athermal martensite in $\mathrm{Fe}-\mathrm{C}$ and $\mathrm{Fe}-\mathrm{N}$ alloys and reported that the martensite in $\mathrm{Fe}-\mathrm{C}$ alloys is harder than that in their $\mathrm{Fe}-\mathrm{N}$ alloy counterparts by approximately $30 \%$ because of the high dislocation density and the strong pinning force on dislocations by the interstitial atoms in $\mathrm{Fe}-\mathrm{C}$ alloys.

\subsection{Tensile Deformation Behavior}

Figure 6 shows nominal stress-strain curves (a) (b) and the changes in the volume fraction of DIM as a function of nominal strain (c) (d) in Base, 0.1C and 0.2C steel (a) (c), and $0.1 \mathrm{~N}$ and $0.2 \mathrm{~N}$ steel (b) (d). In addition, true stressstrain curves and work hardening rate-true strain curves in Base (a), 0.1C (b), and 0.1N steel (c) are shown in Fig. 7. Black and gray lines correspond to the data of metastable austenitic stainless steels ( $\mathrm{Fe}-18 \% \mathrm{Cr}-8 \% \mathrm{Ni}$ alloys), and stable austenitic stainless steels ( $\mathrm{Fe}-18 \% \mathrm{Cr}-12 \% \mathrm{Ni}$ alloys), respectively. In Base steel, the volume fraction of DIM increased from the early stage of deformation, so that the work-hardening rate increased rapidly, which is an expected behavior for the TRIP steel. However, because the DIMT was completed early, uniform elongation (UE) was only of a true strain of approximately 0.3 . On the other hand, in $0.1 \mathrm{C}$ and $0.1 \mathrm{~N}$ steels, the high work-hardening rate continued until the later stage of deformation due to their high austenite stability, resulting in the high UE of true strain of more than 0.5 without reduction in strength. The remarkable variations of the work-hardening rate (serration) at a true strain of more than 0.4 in $0.1 \mathrm{C}$ steel (as shown in Fig. 7(b)) was due to the dynamic strain aging of $\mathrm{C}$ in DIM. ${ }^{17)}$ Although the volume fraction of DIM in $0.1 \mathrm{C}$ steel is lower than that in $0.1 \mathrm{~N}$ steel, $0.1 \mathrm{C}$ steel possesses the high tensile strength (TS). As described in the previous section, this is possibly because DIM generated in $0.1 \mathrm{C}$ steel is harder than that in $0.1 \mathrm{~N}$ steel, and it bears high stress, as described later. When $\mathrm{C}$ and $\mathrm{N}$ were added to a composition of $0.2 \%$, DIMT did
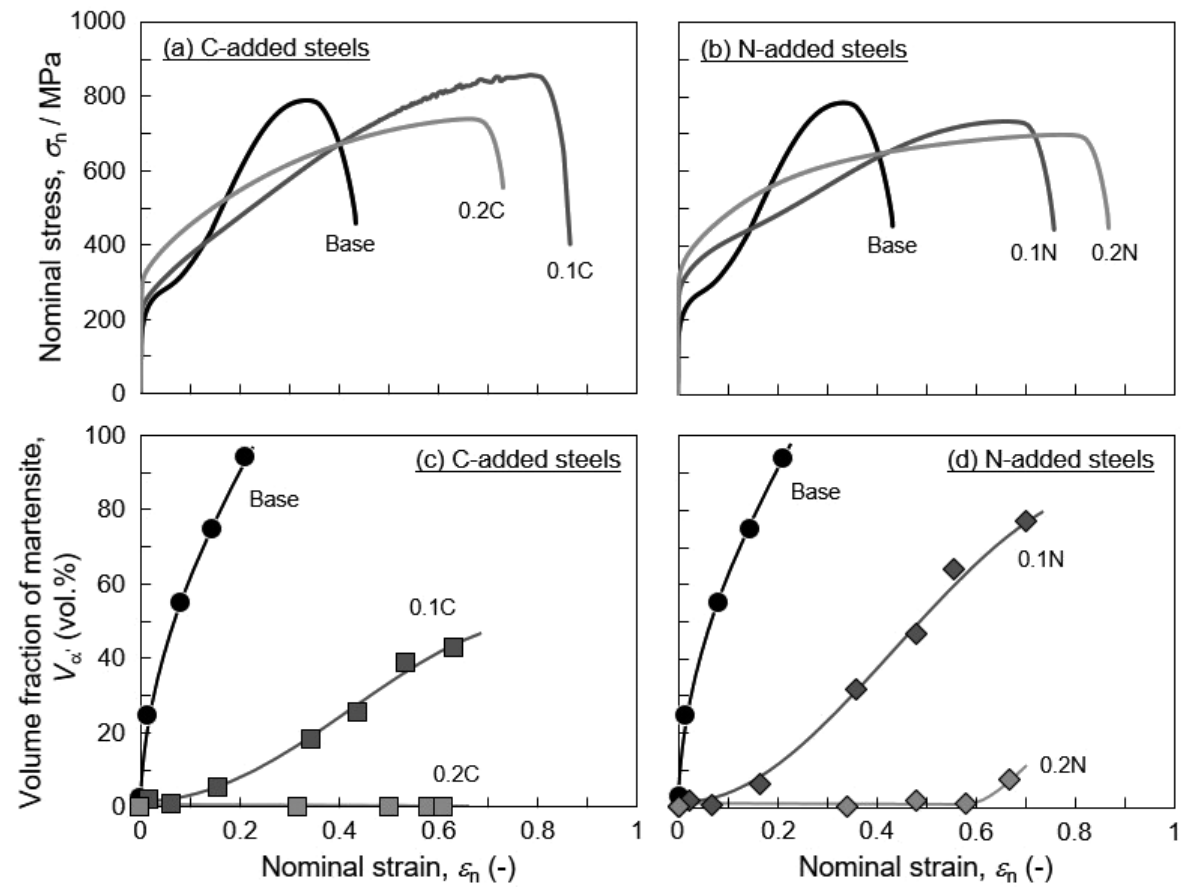

Fig. 6. Nominal stress-strain curves of Base, C-added (a) and N-added steels (b). Changes in volume fraction of DIM as a function of nominal strain in Base, $\mathrm{C}$-added (c), and $\mathrm{N}$-added steels (d). 

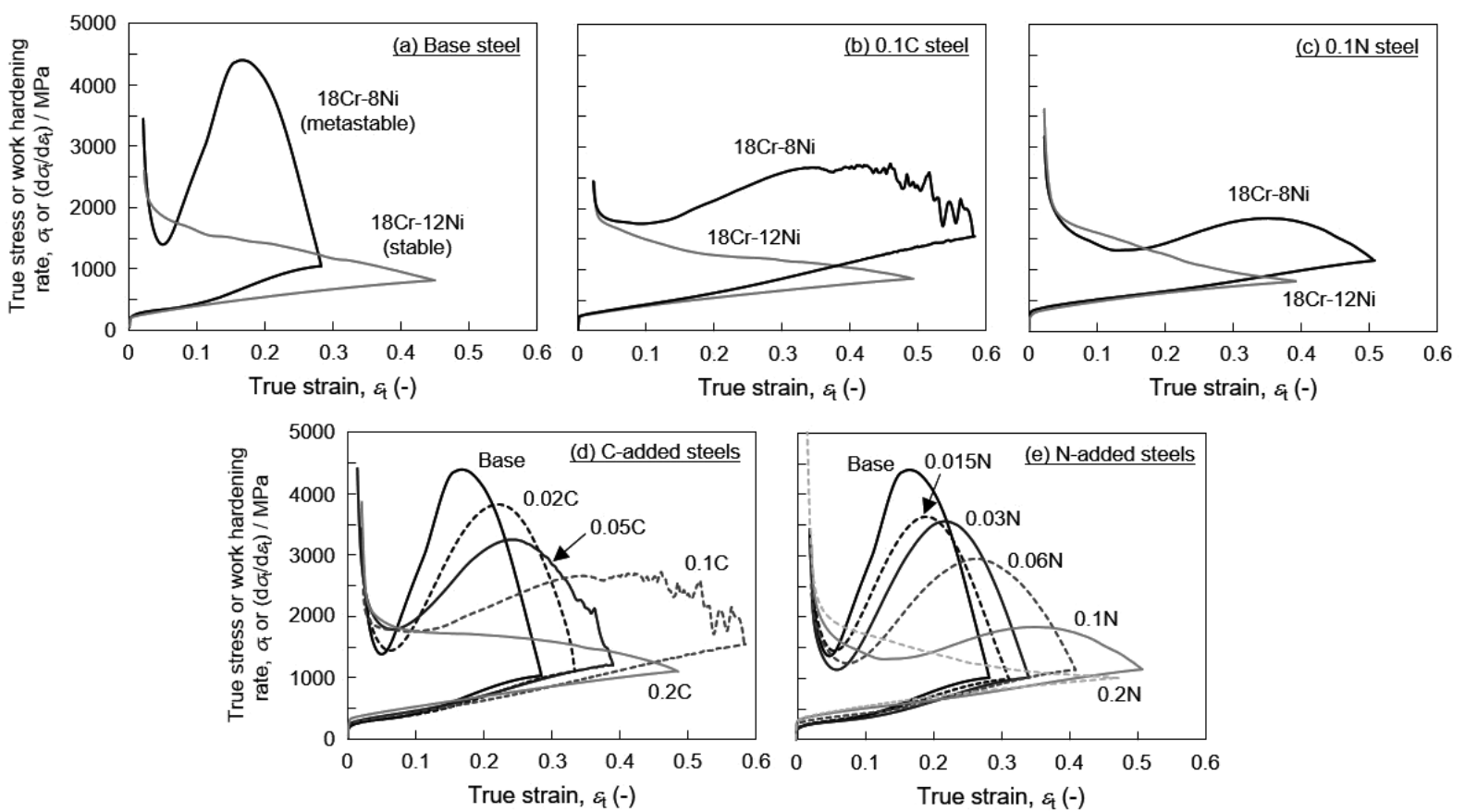

Fig. 7. Changes in true stress and work-hardening rate as a function of true strain in Base (a), $0.1 \mathrm{C}(\mathrm{b})$, and $0.1 \mathrm{~N}$ (c), C-added (d), and $\mathrm{N}$-added steels (e).
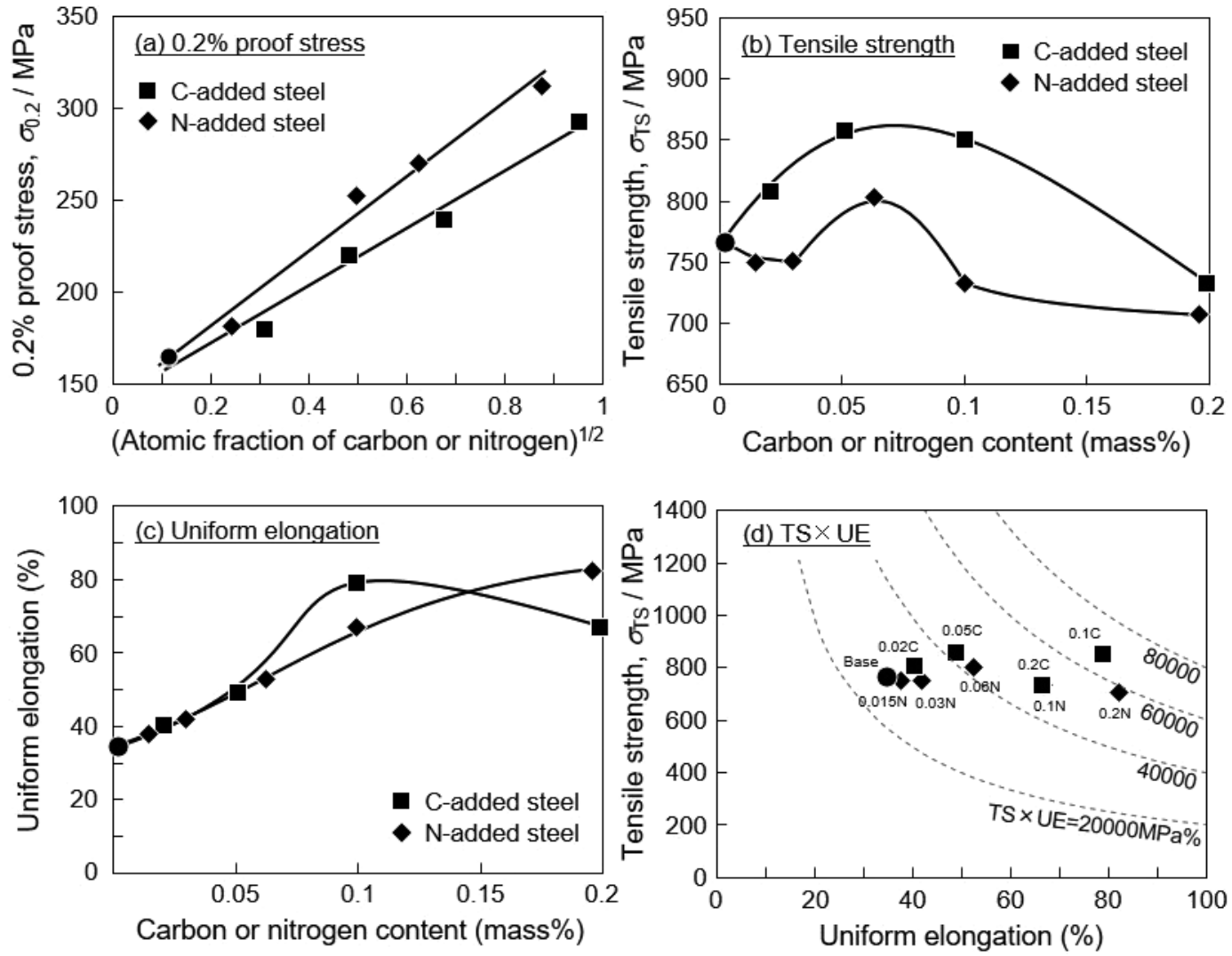

Fig. 8. Changes in $0.2 \%$ proof stress (a), tensile strength (b), uniform elongation (c), and TS $\times$ UE (d) as a function of C or $\mathrm{N}$ content in $\mathrm{Fe}-18 \% \mathrm{Cr}-8 \% \mathrm{Ni}-(\mathrm{C}, \mathrm{N})$ alloys.

not occur during tensile testing, and hence, TS decreased. Figures 7(d) and 7(e) show the work-hardening rate curves of C-added steels (d) and $\mathrm{N}$-added steels (e). With increasing the amount of $\mathrm{C}$ and $\mathrm{N}$, the maximum values of the work-hardening rate decreased due to the austenite stabilization, while the elongation remarkably improved without the reduction in TS. The various tensile properties of each steel are summarized in Fig. 8. As shown in Fig. 8(a), the effect of $\mathrm{N}$ on the $0.2 \%$ proof stress was slightly higher than that of $\mathrm{C}$. One of the reasons suggested is that $\mathrm{Cr}$ and $\mathrm{N}$ form $i-s$ complexes, which have a non-cubic crystalline symmetry, and these complexes contribute to the interstitial-dislocation interaction in austenite. ${ }^{18)}$ Figure $8(\mathrm{~b})$ shows the effects of $\mathrm{C}$ and $\mathrm{N}$ on the TS. The TS of $\mathrm{C}$-added steels is higher than 
that of $\mathrm{N}$-added steels. The TS maximum value is in the range $0.05-0.1 \% \mathrm{C}$ and $\mathrm{N}$ contents because the strength of DIM decreases when the amounts of $\mathrm{C}$ and $\mathrm{N}$ are decreased, and the volume fraction of DIM becomes low when the amount of $\mathrm{C}$ and $\mathrm{N}$ is increased. As for the UE in Fig. 8(c), The UE tends to increase with the addition of $\mathrm{C}$ and $\mathrm{N}$, and this is likely because the TRIP phenomenon continues to occur until the later stage of deformation as the austenite stability increases. However, for $0.2 \mathrm{C}$ steel, in which DIMT does not occur and the TRIP effect does not appear, the UE was lower than that of $0.1 \mathrm{C}$ steel. On the other hand, for $0.2 \mathrm{~N}$ steel, in which DIMT hardly occurs as with $0.2 \mathrm{C}$ steel, its UE rather increased in comparison with that of $0.1 \mathrm{~N}$ steel because of the high work-hardening rate based on the planar dislocation developed in high-N austenitic steel. ${ }^{19-22)}$ Figure $8(d)$ shows the strength-ductility balance $(\mathrm{TS} \times \mathrm{UE})$ in each steel. Compared to Base steel, the strength-ductility balance is improved by increasing the UE in $\mathrm{C}$ - and $\mathrm{N}$-added steels. In particular, 0.1C steel has the highest strength-ductility balance. As mentioned above, the strength and ductility vary depending on the work hardening of austenite, strength, and amount of DIM. Therefore, we can control the mechanical properties of metastable austenitic stainless steel by effectively controlling the content of $\mathrm{C}$ and $\mathrm{N}$.

\subsection{Estimation of the Flow Stress of Deformation- induced Martensite}

The flow stress of DIM during tensile testing was calculated using the secant method, and then, the effect of DIM on the work-hardening behavior in metastable austenitic stainless steel was evaluated. The input data for the secant method are listed in Table 2. For the true stress-strain $(\sigma-\varepsilon)$ curve of the austenite phase, the data of stable austenitic stainless steels in Fig. 7 were fitted to the Swift equation. ${ }^{23)}$

$$
\text { Swift equation: } \sigma=\mathrm{a}(\mathrm{b}+\varepsilon)^{N} \text {, }
$$

where $a, b$, and $N$ are the fitting parameters. Young's modulus and Poisson's ratio for all steels and phases were $200000 \mathrm{MPa}$ and 0.3 , respectively. Furthermore, the changes in the volume fraction of DIM $V_{\alpha^{\prime}}$ during tensile testing as a function of true strain $\varepsilon$ were fitted to the
Matsumura equation. ${ }^{24)}$

Matsumura equation: $V_{\alpha^{\prime}}=1-V_{\gamma 0} /\left(1+\left(k_{p} / p\right) V_{\gamma 0} \varepsilon\right)$,

where $V_{\gamma 0}$ denotes the initial volume fraction of austenite, and $k_{p}$ and $p$ are the fitting parameters. In addition to the above input data, the true stress-strain curves of dualphase steels (Fe-18\% Cr- $8 \% \mathrm{Ni}$ alloys) were applied to the calculation. As a result of the calculation using the secant method, ${ }^{11,25)}$ the true stress-strain curves of the DIM single phase can be obtained. Figure 9 shows the calculation results for Base (a) (d), 0.1C (b) (e), and $0.1 \mathrm{~N}$ steel (c) (f). The input data (the true stress-strain curves of $\mathrm{Fe}-18 \% \mathrm{Cr}$ $8 \% \mathrm{Ni}$ alloys (austenite $+\mathrm{DIM}$ ) and $\mathrm{Fe}-18 \% \mathrm{Cr}-12 \% \mathrm{Ni}$ alloys (austenite), and the volume fraction of DIM) are plotted as open marks, and the output data (the true stress-strain curves of DIM) are plotted as solid marks. The input data and corresponding output data are connected with dotted lines. The strength of DIM might be different between the one formed at the early stage of deformation and strained by cold rolling, and the one transformed at a later stage of deformation from heavily deformed austenite; however, the output data represent the average of the strength of various DIMs. In Base steel, although approximately $70 \%$ of DIM has been already transformed at a true strain of 0.1 , the flow stress of Base steel ( $\mathrm{Fe}-18 \% \mathrm{Cr}-8 \% \mathrm{Ni}$ alloys) was almost

Table 2. Input data of Young's modulus $E$, Poisson's ratio $v$, and fitting parameters in Swift equation and Matsumura equation for the secant method.

\begin{tabular}{|c|c|c|c|c|c|c|c|c|}
\hline & & \multirow[t]{2}{*}{$E(\mathrm{MPa})$} & \multirow[t]{2}{*}{$v$} & \multicolumn{3}{|c|}{ Swift equation } & \multicolumn{2}{|c|}{$\begin{array}{l}\text { Matsumura } \\
\text { equation }\end{array}$} \\
\hline & & & & $\mathrm{a}$ & $\mathrm{b}$ & $\mathrm{N}$ & $k_{\mathrm{p}}$ & $p$ \\
\hline \multirow{2}{*}{ Base steel } & $\gamma$ & 200000 & 0.3 & 1216 & 0.035 & 0.62 & \multirow{2}{*}{36.3} & \multirow{2}{*}{1.14} \\
\hline & $\alpha$ & 200000 & 0.3 & - & - & - & & \\
\hline \multirow{2}{*}{$0.1 \mathrm{C}$ steel } & $\gamma$ & 200000 & 0.3 & 1209 & 0.070 & 0.64 & \multirow{2}{*}{11.0} & \multirow{2}{*}{2.44} \\
\hline & $\alpha$ & 200000 & 0.3 & - & - & - & & \\
\hline \multirow{2}{*}{$0.1 \mathrm{~N}$ steel } & $\gamma$ & 200000 & 0.3 & 1193 & 0.044 & 0.48 & \multirow{2}{*}{109.6} & \multirow{2}{*}{3.57} \\
\hline & $\alpha$ & 200000 & 0.3 & - & - & - & & \\
\hline
\end{tabular}
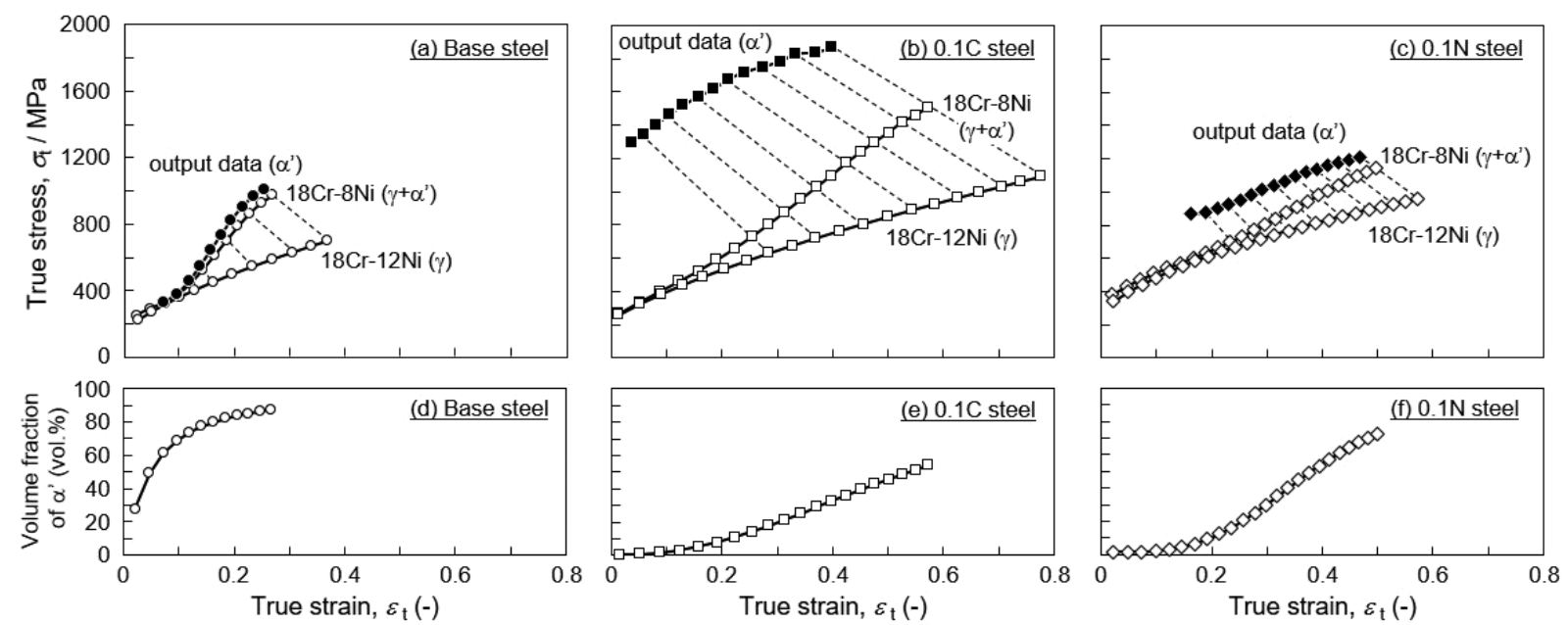

Fig. 9. True stress-strain curves of DIM calculated by the secant method (solid marks), Fe- $18 \% \mathrm{Cr}-8 \% \mathrm{Ni}-(\mathrm{C}, \mathrm{N})$ alloys, and $\mathrm{Fe}-18 \% \mathrm{Cr}-12 \% \mathrm{Ni}-(\mathrm{C}, \mathrm{N})$ alloys (open marks) in Base (a), 0.1C (b), and 0.1N steel (c). Changes in volume fraction of DIM as a function of true strain in Base (d), $0.1 \mathrm{C}(\mathrm{e})$, and $0.1 \mathrm{~N}$ steel (f). 
identical to that of austenite (Fe-18\% Cr-12\%Ni alloys), indicating that DIM hardly contributes to the strengthening below the true strain of 0.1 . This is because there is not much difference in the strength between austenite and DIM in the Base steel at the early stage of deformation, as indicated by the result of the nano-indentation test in Fig. 4. As the deformation progressed, the Base steel underwent significant work hardening, and its flow stress largely deviated from that of austenite. The true stress-strain curve of DIM is almost the same as that of Base steel because austenite is mostly transformed into DIM. For $0.1 \mathrm{C}$ steel, a larger work hardening was confirmed immediately after the start of DIMT, unlike the Base steel. The stress of DIM was as high as $1200 \mathrm{MPa}$ at the strain where DIMT began. Because the difference in the strength of austenite and DIM is large and DIMT gradually progresses in the $0.1 \mathrm{C}$ steel, the work-hardening behavior becomes different from that of the Base steel. On the other hand, the large increase in the work hardening of $0.1 \mathrm{~N}$ steel started at a strain of approximately 0.3 , where there was approximately $20 \%$ DIM, and the strength of DIM is between Base and $0.1 \mathrm{C}$ steels. Thus, the strength and work-hardening behavior of metastable austenitic steel significantly depends on the strength of DIM. Because the highest stress of DIM was obtained in $0.1 \mathrm{C}$ steel, followed $0.1 \mathrm{~N}$ and Base steel, respectively, it is concluded that the TRIP effect could be improved due to the strengthening of DIM by the addition of $\mathrm{C}$ and $\mathrm{N}$, although the amount of DIM decreased. Particularly in $0.1 \mathrm{C}$ steel, an excellent strength-ductility balance was achieved compared with $0.1 \mathrm{~N}$ steel because the remarkably hard DIM was gradually formed until the later stage of deformation.

\section{Conclusions}

The effects of $\mathrm{C}$ and $\mathrm{N}$ on the strength of DIM in metastable austenitic stainless steel (Fe-18\%Cr- $8 \% \mathrm{Ni}$ alloy) were investigated, and then, the work hardening behavior was determined. The conclusions are summarized as follows:

(1) The mechanical stabilization effect of $\mathrm{C}$ was higher than that of N. Although the volume fraction of DIM of $\mathrm{C}$-added steels was lower than that of $\mathrm{N}$-added steels, $\mathrm{C}$ was more effective in increasing the work-hardening rate and the hardness of cold-rolled metastable austenitic stainless steels than N. This is because the effect of $\mathrm{C}$ on the strengthening of the DIM is higher than that of N. Therefore, the hardening of DIM by the addition of $\mathrm{C}$ and $\mathrm{N}$ is effective for improving the work hardening.

(2) The strength-ductility balance of metastable austenitic stainless steel was improved by adding $\mathrm{C}$ and $\mathrm{N}$, and better properties were obtained in $\mathrm{C}$-added steels compared to $\mathrm{N}$-added steels. The calculation using the secant method revealed that this observation is because DIM containing $\mathrm{C}$ and $\mathrm{N}$ bears higher stress during tensile testing. In $0.1 \mathrm{C}$ steel, an excellent strength-ductility balance was achieved compared with $0.1 \mathrm{~N}$ steel because the remarkably hard DIM is gradually formed until the later stage of deformation.

\section{Acknowledgement}

This study was supported by the 27th ISIJ (Iron and Steel Institute of Japan) Research Promotion Grant and JSPS KAKENHI Grant Number JP20K15050. We would like to thank Dr. Takahito Ohmura (National Institute for Materials Science (NIMS)) for advice on nano-indentation and Prof. Noriyuki Tsuchida (University of Hyogo) for the lectures on the secant method.

\section{REFERENCES}

1) N. Tsuchida, Y. Morimoto, T. Tonan, Y. Shibata, K. Fukaura and R. Ueji: ISIJ Int., 51 (2011), 124. https://doi.org/10.2355/ isijinternational.51.124

2) J. P. Bressanelli and A. Moskowitz: Trans. Am. Soc. Met., 59 (1966), 223.

3) M. Yoshitake, T. Tsuchiyama and S. Takaki: Tetsu-to-Hagané, 98 (2012), 223 (in Japanese). https://doi.org/10.2355/tetsutohagane.98.223

4) T. Masumura, N. Nakada, T. Tsuchiyama, S. Takaki, T. Koyano and K. Adachi: Acta Mater., 84 (2015), 330. https://doi.org/10.1016/j. actamat.2014.10.041

5) T. Masumura, K. Fujino, T. Tsuchiyama, S. Takaki and K. Kimura: Tetsu-to-Hagané, 105 (2019), 1163 (in Japanese). https://doi. org/10.2355/tetsutohagane.TETSU-2019-062

6) T. Masumura, K. Fujino, T. Tsuchiyama, S. Takaki and K. Kimura: ISIJ Int., 61 (2021), 546. https://doi.org/10.2355/isijinternational. ISIJINT-2020-719

7) T. Tsuchiyama, K. Inoue, K. Hyodo, D. Akama, N. Nakada, S. Takaki and T. Koyano: ISIJ Int., 59 (2019), 161. https://doi. org/10.2355/isijinternational.ISIJINT-2018-404

8) N. H. K. Luan: Ph.D. thesis, Kyushu University, (2012), 93.

9) K. Takano, M. Sakakibara, T. Matsui and S. Takaki: Tetsu-toHagané, 86 (2000), 123 (in Japanese). https://doi.org/10.2355/ tetsutohagane1955.86.2_123

10) H. K. L. Ngo, K. Nakashima, T. Tsuchiyama and S. Takaki: Tetsuto-Hagané, 98 (2012), 25 (in Japanese). https://doi.org/10.2355/ tetsutohagane. 98.25

11) G. J. Weng: J. Mech. Phys. Solids, 38 (1990), 419. https://doi. org/10.1016/0022-5096(90)90007-Q

12) Y. Onuki, T. Masumura, T. Tsuchiyama, S. Sato, T. Tomida and S. Takaki: Tetsu-to-Hagané, 106 (2020), 457 (in Japanese). https://doi. org/10.2355/tetsutohagane.TETSU-2019-103

13) W. C. Oliver and G. M. Pharr: J. Mater. Res., 7 (1992), 1564. https:// doi.org/10.1557/JMR.1992.1564

14) N. Nakada, H. Ito, Y. Matsuoka, T. Tsuchiyama and S. Takaki: Acta Mater., 58 (2010), 895. https://doi.org/10.1016/j.actamat.2009.10.004

15) N. Saenarjhan, J. H. Kang and S. J. Kim: Mater. Sci. Eng. A, 742 (2019), 608. https://doi.org/10.1016/j.msea.2018.11.048

16) Y. Tian, O. I. Gorbatov, A. Borgenstam, A. V. Ruban and P. Hedström: Metall. Mater. Trans. A, 48 (2017), 1. https://doi. org/10.1007/s11661-016-3839-2

17) T. Ogawa, M. Koyama, C. C. Tasan, K. Tsuzaki and H. Noguchi: J. Mater. Sci., 52 (2017), 7868. https://doi.org/10.1007/s10853-0171052-3

18) V. Gavriljuk and H. Berns: High Nitrogen Steels, Springer, Berlin, (1999), 137. https://doi.org/10.1007/978-3-662-03760-7

19) T. Masumura, Y. Seto, T. Tsuchiyama and K. Kimura: Netsu Shori (J. Jpn. Soc. Heat Treat.), 59 (2019), 222 (in Japanese). https://doi. org/10.14940/netsushori.59.222

20) T. Masumura, Y. Seto, T. Tsuchiyama and K. Kimura: Mater. Trans., 61 (2020), 678. http://doi.org/10.2320/matertrans.H-M2020804

21) M. Ojima, Y. Adachi, Y. Tomota, K. Ikeda, T. Kamiyama and Y. Katada: Mater. Sci. Eng. A, 527 (2009), 16. https://doi.org/10.1016/j. msea.2009.07.066

22) S. Kubota, Y. Xia and Y. Tomota: ISIJ Int., 38 (1998), 474. https:// doi.org/10.2355/isijinternational.38.474

23) H. W. Swift: J. Mech. Phys. Solids, 1 (1952), 1. https://doi. org/10.1016/0022-5096(52)90002-1

24) O. Matsumura, Y. Sakuma and H. Takechi: Scr. Metall., 21 (1987), 1301. https://doi.org/10.1016/0036-9748(87)90103-7

$25)$ N. Tsuchida and Y. Tomota: Mater. Sci. Eng. A, 285 (2000), 346. https://doi.org/10.1016/S0921-5093(00)00688-2 